\section{Praktisk lærebok i psykiatri}



Alv A. Dahl, Trond F. Aarre, red.

698 s, tab, ill. Bergen: Fagbokforlaget, 2012.

Pris NOK 725

ISBN 978-82-450-1172-2

Denne læreboken er beregnet på medisinstudenter, leger og andre faggrupper i primærhelsetjenesten etter at samhandlingsreformen trådte i kraft i Norge. Da ble primærhelsetjenestens ansvar for psykiatriske tilstander mye større.

Redaktørene innleder med et kapittel om definisjon av faget og innføring i organisering, klassifikasjon og epidemiologi. Kapitlet om forståelsesmodeller omhandler nevrobiologisk, psykodynamisk, læringsteoretisk, kognitiv og sosial modell og samvirket mellom disse modellene for å forstå helheten. I to kapitler, om å være psykiatrisk pasient og å være pårørende til psykisk syke, legger forfatterne vekt på den subjektive opplevelsen av pasient- og pårørenderollen.

Etter et kapittel om den psykiatriske undersøkelsen følger 14 kapitler om tilstandsbilder, mens de siste kapitlene omhandler behandlingsformer, rettspsykiatri, psykiatri i allmennpraksis og brukermedvirkning.

Kapitlene er oversiktlig utformet med illustrerende kasuistikker i blå tekstbokser. Hvert kapittel har ca. 20 referanser, mange fra de senere årene.

Forfatterne har høy kompetanse på sitt område. Redaktørene har prøvd å få enhetlige kapitler, men har ivaretatt forfatternes preferanser. Dette har medført en del selvmotsigelser, for eksempel skrives det i kapitlet om spiseforstyrrelser at familiearbeid hovedsakelig er viktig fordi spiseforstyrrelsen påvirker familiemedlemmer sterkt. I kapittel 20, Psykoterapi med fokus på allmennpraksis, omtales «familieterapi (-) bedre enn behandling som ikke omfatter familien ved schizofreni, alkohol- og stoffmisbruk, anorexia nervosa, demens og hos deprimerte kvinner i problemfylte ekteskap. Familieterapi er bedre enn ingen behandling ved alle disse lidelsene samt ved fedme. Sikre skadevirkninger av familieterapi er ikke dokumentert».

Redaktørene har oppfylt sitt mål om en psykiatribok med vekt på primærhelsetjenesten. Oppdatert kunnskap om behandlingsprinsipper kan inspirere leserne til å ta ansvar for pasienten lenger, før de henviser til spesialisthelsetjenesten.

I første kapittel minner forfatterne om at samfunnets utgifter og tapte inntekter er langt høyere for psykiske lidelser enn for noen somatisk sykdomsgruppe, som kreft eller hjerte- og karlidelser.

Primærhelsetjenesten vil møte en stadig sterkere brukerbevissthet hos pasienter og deres pårørende. Det er prisverdig at deres stemme kommer frem gjennom mange kapitler.

Jeg savner omtaler av barn som pårørende, og barne- og ungdomspsykiatriske pasienter, som i en alder av 18 år plutselig blir voksenpsykiatriens ansvar. Samarbeidet i skjæringsfeltet mellom barne- og voksenpsykiatrien fortjener et eget kapittel.

Med så mange forfattere og temaer trenger man et fyldigere stikkordregister. Her vil jeg nevne ord som allianse, etikk, kjønn, mentalisering, minoriteter, relasjoner, resiliens, tilknytning og traumer-begreper som omtales flere steder, men som er vanskelig å finne i teksten.

Jeg anbefaler boken til medisinstudenter og leger, i tillegg til andre faggrupper i primærhelsetjenesten.

\section{$\emptyset y s t e i n$ Sørbye}

Klinikk psykisk helse og avhengighet

Oslo universitetssykehus

\section{Fremad - og aldri glemme!}

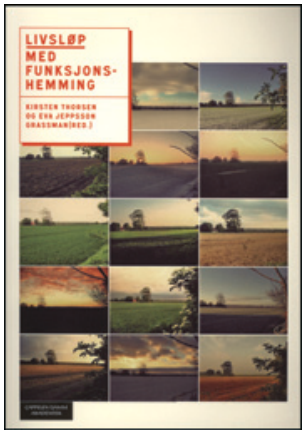

Kirsten Thorsen, Eva Jeppson Grassman, red. Livsløp med funksjonshemming

344 s. Oslo: Cappelen Damm, 2012.

Pris NOK 398

ISBN 978-82-02-37771-7

Forfatterne er norske og svenske samfunnsforskere med bred tverrfaglig bakgrunn og betydelig forskningserfaring rundt ulike sider ved funksjonshemmedes levekår.

Livsløpsbegrepet definerer sosiale hendelser og roller som løper gjennom menneskers liv. Sentralt står tids- og stedsdimensjonen, relasjonen til andre mennesker og aktørenes livsvalg. Menneskers biografi formes i relasjon til tidsalderens rådende sosiale og kulturelle normer. For minoriteter med avvik fra normen blir betydningen av endringer i tidens dominerende tankesett enda tydeligere. $\AA$ vokse opp med funksjonshemning på 1950-tallet var en ganske annen affære enn i dag! Livsløpsblikket stiller tidsepokene i relieff og fremtvinger refleksjoner også over majoritetens livsløp.

Selv om livsløpsbegrepet omfatter alle faser i livet, og ikke minst overgangene mellom fasene, er denne utgivelsen mest viet aldringens utfordringer. Å bli eldre berører status og rolleforståelse, kroppens fysiske forfall og eksistensielle spørsmål. Visse grupper funksjonshemmede nådde før i tiden sjelden høy alder. Disse gruppene utgjør nå en førstegenerasjon som må finne ut av, og samtidig kan påvirke, hva det vil si å aldres med en funksjonshemning. Gjør dette dem mer lik resten av befolkningen? Oppstår det nye distinksjoner?

Bidragsyterne beskriver en rekke ulike livsløp. Tiden etter hjerneskaden belyses gjennom dualiteten brudd/kontinuitet, mentale prosesser knyttet til stahet, reorientering og omstilling, og utforskningen av hvilke fleksible tilpasninger den enkelte er i stand til å foreta. Funksjonshemning og kjønnsidentitet, poliorammedes økende tap av arbeidsevne og pårørendeopplevelser vies egne kapitler. «Dobbelt aldring» sikter til parallelle historier fortalt av psykisk utviklingshemmede og omsorgspersonene. Den sosialpolitiske utviklingen danner bakteppet: avviklingen av spesialinstitusjonene og den skjellsettende innflyttingen i egen bolig. Hvordan blir disse menneskenes siste livsfase? Ny institusjonalisering, $\mathrm{i}$ «normaliseringens» tegn, til ukjente omgivelser og tap av relasjoner?

Psykisk lidelse i livsløpsperspektiv vektlegger lange, tålmodige bedringsprosesser. Uten ambisjon om helbredelse dreier det seg om å leve i hverdagen best mulig, gjennom å utvikle og vedlikeholde kontekster som skaper mening.

Teksten er på sitt beste når forfatterne drøfter funksjonshemning, identitet og medisinske, sosiale og relasjonelle forståelsesmodeller ut fra livsløpsperspektivet. Den stimulerer interessen for det biografiske mennesket bak diagnosen.

Jeg anbefaler boken til alle som arbeider med somatisk og psykisk funksjonshemmede eller pasienter med kroniske lidelser. Den kan også leses av den som reflekterer over sitt eget livsløp med en funksjonshemning. Boken bør også leses av folk innen styre og stell, og helst de (unge) som skal yte tjenestene innen morgendagens helse- og sosialsektor. Når det gjelder utfordringene knyttet til aldring og alderdom, må vi huske at god kjennskap til fortiden livsløpsforståelsen - danner grunnlaget for nåtiden.

\section{Sven Conradi}

Sunnaas sykehus 